This journal is the official publication of Bangladesh Society of Physiologists (BSP)

Web URL: www.banglajol.info/index.php/JBSP

Abstracted /indexed in Index Copernicus, Director of Open Access Journal, Index Medicus for South East Asia Region, Google Scholar, 12OR, infobse index, Open J gate, Cite factor, Scientific indexing services

pISSN-1983-1213; e-ISSN-2219-7508

\title{
Article
}

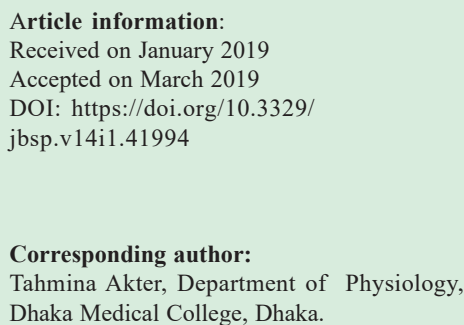

This article is open access licensed under CC BY NC SA which allows readers copy, distribute, display, and perform the work and make derivative works based on it only for noncommercial purposes.

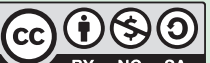

\section{Effect of Emblica Officinalis (amloki) on iron status in pregnant women with iron deficiency anaemia}

\author{
Tahmina Akter ${ }^{1}$, Qazi Shamima Akhter ${ }^{1}$ \\ 1. Department of Physiology, Dhaka Medical College, Dhaka.
}

\section{Abstract}

Background: Common clinical practice of prescribing Iron supplementation for Iron deficiency anemia (IDA) in pregnancy is associated with a number of side effects. Emblica officinalis (amloki) is a well known dietary supplement used by traditional practitioners to treat anemia. Objective: To evaluate the effects of oral supplementation of Emblica officinalis on iron status in pregnant women with IDA. Methods: This prospective interventional study was carried out in the Department of Physiology, Dhaka Medical College (DMC), Dhaka from July 2016 to June 2017 on 43 pregnant women aged 18 to 36 years between $13^{\text {th }}$ to $20^{\text {th }}$ weeks of gestation with IDA. They were recruited from the Out-patient department of Obstetrics and Gynaecology, DMC Hospital. Among them 24 were supplemented with amloki and iron (IAS) and 19 women received only iron supplementation (IS). Study variables were estimated at the baseline and after 45 days of supplementation. Serum iron, ferritin and Total iron binding capacity (TIBC) were estimated following standard laboratory methods. Data were expressed as mean \pm SD. Paired and Unpaired Student's t-test were used for statistical analysis. Results: Serum iron levels were significantly higher $(\mathrm{p}<0.001)$ and serum TIBC were significantly lower $(\mathrm{p}<0.001)$ in both groups after supplementation compared to their baseline value. But post supplementation serum ferritin level was significantly higher $(p<0.01)$ only in IAS group compared to that of the baseline. Again, after intervention, serum iron level was significantly higher $(\mathrm{p}<0.05)$ and serum TIBC was significantly lower $(\mathrm{p}<0.01)$ in IAS group when compared with those of IS group. Conclusions: Data concluded that oral Emblica officinalis supplement along with iron was more effective than only iron supplementation to improve serum iron status in pregnant women with IDA.

Keywords: Iron deficiency anaemia, pregnancy, amloki, iron status 
Introduction

A nemia is a worldwide public health problem. Among different types of anemia iron deficiency anemia is the most common type ${ }^{1-3}$. According to the survey of 1995-96 in Bangladesh, the prevalence of anemia in pregnant women was $59 \%{ }^{4}$.

Iron deficiency anaemia (IDA) develops when there is inadequate iron for haemoglobin synthesis due to poor intake, decreased absorption, chronic blood loss and increased demand in growth and pregnancy ${ }^{5}$.

Different surveys conducted in Bangladesh revealed that over $95 \%$ of the dietary iron was contributed by plant sources. Plant sources have poor bioavailability of iron due to its ferric form and presence of absorption inhibitors like, phytates $^{4,6-7}$. Again, during pregnancy maternal blood volume increases and there is increased demand of iron for the growth of the fetus. Pregnancy also reduces the erythropoietic function of bone marrow. All these factors make a pregnant woman iron deficient, though she was previously healthy ${ }^{8-9}$.

WHO has classified IDA amongst the top ten selected health risks ${ }^{10}$. Iron deficiency anemia is associated with increased incidence of preterm labor and low birth weight babies and adverse obstetric outcomes like cardiac failure, puerperal sepsis, decreased lactation due to inability to cope with the stress of child birth ${ }^{8,11}$.

In chronic IDA, the cellular indices show a microcytic and hypochromic erythropoiesis. but normocytic normochromic blood picture is not uncommon ${ }^{7}$. Low serum iron and ferritin levels with an elevated total iron-binding capacity (TIBC) are diagnostic of iron deficiency ${ }^{12}$.

Pregnancy is associated with increased demand of all the nutrients like iron $(\mathrm{Fe})$, copper $(\mathrm{Cu})$, zinc (Zn), vitamin B12, folic acid and ascorbic acid, so it is not possible to correct anemia only by Fe supplementation. Emblica officinalis (amloki) is a well known dietary supplement in
Ayurveda used in the management of IDA during pregnancy $^{13}$. It is the fruit of Phyllanthus emblica, latin name is Emblica officinalis belongs to the Family: Euphorbiaceae ${ }^{14}$. It is a rich source many minerals, enzymes acids and vitamins especially vitamin $\mathrm{C}$. This edible fruit tissue contains vitamin $\mathrm{C}$ more than those in oranges and lemons ${ }^{13,15-16}$.

Recently, natural products are preferred in alternative medicine. Herbal medicines are commonly used and considered as a convenient treatment because of their safety, efficacy and cost effectiveness as well as better compatibility. About $80 \%$ of the world's population depends on traditional medicine for their primary health care $^{15}$.

Though WHO has recommended iron and folic acid supplementation as standard treatment for IDA in pregnancy ${ }^{17}$ but it is not free from untoward effects including heart burn, nausea, constipation etc. Recently it has been shown to generate free radicles, which cause damage to the intestine ${ }^{18}$. But if the Amloki is added with iron pills it raises its absoption and decreases the side effects ${ }^{9}$. Adding vitamin $\mathrm{C}$ to a meal increases non-heme iron absorption upto six fold which makes the absorption of non- heme iron as good as or better than that of heme iron ${ }^{1}$. Combination of amloki with $\mathrm{FeSO}_{4}$ can enhance iron absorption 3 fold over the control iron preparation of $\mathrm{FeSO}_{4}$ alone ${ }^{19}$.

On the basis of this background, the present study has been designed to evaluate the effect of amloki on serum iron status in pregnant women with iron deficiency anaemia.

\section{Methods}

This prospective interventional study was conducted in Department of Physiology, Dhaka Medical College, Dhaka from July 2016 to June 2017, on 43 pregnant women attending outpatient department of Obstetrics and Gynaecology, DMCH. This study obtained ethical clearance from Research Review committee and Ethical

J Bangladesh Soc Physiol. 2019, June; 14(1): 1-6 
Review Committee of Dhaka Medical College, Dhaka. The participants were in the age group of 18 to 36 years with $13^{\text {th }}$ to $20^{\text {th }}$ weeks of gestation. An informed written consent was collected from each subject. A detailed of history about socio economic condition, food habit, parity as well as menstrual history were taken along with haematological examination records. All subjects were free from any known cardiac, renal, liver, endocrine or blood disorder. Clinically diagnosed and confirmed patients of iron deficiency anaemia were selected and divided into two groups, 24 pregnant women in group IDA, were supplemented with oral amloki capsule (1.072 gm, 2capsules of 536mg) thrice daily and iron tablet [ferrous fumarate $(200 \mathrm{mg})+$ folic acid $(0.02 \mathrm{mg})]$ once daily for 45 days were considered as study group (IAS). Another 19 pregnant women with IDA, were supplemented with only iron tablet were considered as control group (IS).

At the beginning of the study, 25 subjects were selected for study group and 21 for control group. After selection of the subjects, the nature, purpose and benefit of the study were explained to each subject in details. All the information were recorded in a prefixed data sheet. Iron status was estimated by measuring serum iron, ferritin levels and TIBC using standard laboratory technique. These parameters were studied at the beginning of the study (baseline) and after 45 days of study period in all subjects. Compliance to the supplementation was monitored by regular telephonic communications. Amloki capsules were given in boxes for 45 days and participants were encouraged to continue the supplied medicine daily. After 2 weeks of study period one subject was excluded from study group due to reluctance. After 4 weeks of study, 2 subjects from control group left Dhaka. So, finally 24 subjects of study and 19 subjects of control groups completed the study.

The amloki capsule (Amlahills) used in this study was manufactured by Isha Agro Developers PVT.LTD, India and certified by the Department of Pharmaceutical Chemistry, Faculty of Pharmacy, University of Dhaka.

For statistical analysis Paired Student's 't' test and Unpaired Student's ' $t$ ' test were performed using SPSS Version 22.0. Data were expressed as mean $\pm \mathrm{SD}$. The $p$ value $<0.05$ was taken as level of significance.

\section{Results}

Baseline characteristics of all subjects are presented in Table I and there was no significant difference between study and control groups. Serum iron level was significantly higher $(\mathrm{p}<0.01)$ and serum TIBC was significantly lower $(p<0.001)$ compared to their baseline values in both groups. But ferritin levels were significantly increased after supplementation only in IAS group compared to that of the baseline value. In addition, post supplementation values of serum iron and TIBC were also significantly different between two groups (Table II).

Table I: General characteristics of the subjects in both groups $(\mathrm{N}=43)$

\begin{tabular}{lcc}
\hline Variables & IS $(\mathrm{n}=19)$ & IAS $(\mathrm{n}=24)$ \\
\hline Age (years) & $25.53 \pm 6.13$ & $24.13 \pm 4.38$ \\
Height $(\mathrm{cm})$ & $151.98 \pm 13.17$ & $154.65 \pm 9.82$ \\
Weight $(\mathrm{kg})$ & $51.92 \pm 7.75$ & $54.71 \pm 7.10$ \\
BMI $\left(\mathrm{kg} / \mathrm{m}^{2}\right)$ & $21.88 \pm 2.85$ & $22.49 \pm 2.75$ \\
Systolic BP $(\mathrm{mm}$ of Hg) & $101.05 \pm 9.94$ & $105.83 \pm 10.18$ \\
Diastolic BP (mm of Hg) & $64.74 \pm 6.97$ & $68.75 \pm 13.61$ \\
Gestational age (Weeks) & $15.36 \pm 2.19$ & $16.12 \pm 2.57$ \\
\hline
\end{tabular}

Results are expressed as mean $\pm \mathrm{SD}$. Unpaired and paired $t$ test was performed to compare between groups. IS = Iron supplemented, IAS = Iron and Amloki Supplement 
Table II: Serum iron, ferritin levels and total iron binding capacity (TIBC) in different groups ( $N=43$ )

\begin{tabular}{|c|c|c|c|c|}
\hline \multirow[t]{2}{*}{ Variables } & \multicolumn{2}{|c|}{ IS(n=19) } & \multicolumn{2}{|c|}{$\operatorname{IAS}(n=24)$} \\
\hline & Baseline & After 45 days & Baseline & After 45 days \\
\hline $\operatorname{Iron}(\mu \mathrm{g} / \mathrm{dl})$ & $47.42 \pm 10.08$ & $116.94 \pm 16.64^{\# \#}$ & $50.00 \pm 7.40$ & $135.00 \pm 18.87^{* *}$ \\
\hline Ferritin(ng/dl) & $10.37 \pm 4.40$ & $10.95 \pm 4.13$ & $12.12 \pm 6.17$ & $13.41 \pm 6.30^{*}$ \\
\hline $\operatorname{TIBC}(\mu \mathrm{g} / \mathrm{dl})$ & $508.95 \pm 40.57$ & $343.42 \pm 52.48^{\# \#}$ & $494.63 \pm 82.16$ & $297.21 \pm 30.38^{* * \bullet "}$ \\
\hline
\end{tabular}

Data were expressed as mean $\pm S D$. Paired $t$ test was performed for comparison within groups and unpaired $t$ test was performed to compare between groups. $\left({ }^{\#}=\right.$ IS baseline vs IS after 45 days; ${ }^{*}=$ IAS baseline vs IAS after 45 days; " = IS after 45 days vs IAS after 45 days $)^{*}=\mathrm{p}<0.01,{ }^{* * / \# \# /{ }^{\prime \prime} "}=\mathrm{p}<0.001$. $\mathrm{N}=$ Total number of subjects, $\mathrm{n}=$ number of subjects in each group IS = Iron supplemented, IAS = Iron and Amloki Supplement

\section{Discussion}

In this study, the increased serum iron and decreased TIBC in amloki and iron supplemented group in comparison to only iron supplemented group agree to others ${ }^{11,20,21}$.

On contrary, Benjwal found significant increase in serum ferritin level in amloki and iron treated group in comparison to only iron treated group ${ }^{22}$. They used elemental iron according to body weight for all the subjects, which may cause the difference. Literature review suggested that, along with other nutrients, demand of iron also increased for the development of fetus and placenta and to expand maternal erythrocyte mass during pregnancy ${ }^{23}$. Iron is found in ferrous/ferric form at the site of absorption of the intestine. Reduction of ferric to ferrous form is necessary for the absorption of iron. Ferric reductase (Dcytb) present on the brush border of enterocytes causes this reduction. Other dietary factor like vitamin $\mathrm{C}$ can also cause this reduction and enhance iron absorption. Vitamin $\mathrm{C}$ present in amloki is the most potent enhancer of iron absorption by its reduction to ferrous form ${ }^{19}$. Moreover, phytates present in cereals and legumes impair absorption of iron from foods as well as from soluble iron salts. Phytates form diferric and tetraferric phytates, which are insoluble in gastric environment ${ }^{24}$. Vitamin $\mathrm{C}$ can counteract the inhibitory effect of phytates by replacing it from iron and make iron soluble for better absorption ${ }^{6}$. Iron is stored as ferritin (the major storage form of iron) in macrophages. Estimation of serum ferritin is the most accurate test to diagnose iron deficiency anaemia. A progressive increase in serum ferritin level is the sign that the therapeutic agent is effective in replenishing the body iron store $8,25,26$. Total iron binding capacity (TIBC) is an indicator of the extent of iron deficiency. In iron deficiency anaemia serum TIBC level is increased. Therefore if any therapy reduces serum TIBC, it is indicative of the correction of the underlying cause. Greater the reduction in TIBC level better the response to therapy ${ }^{10,27}$. In this study, serum iron, ferritin levels were significantly increased and serum TIBC was significantly decreased in IAS group in comparison to their baseline value. Again, serum iron levels were significantly increased and serum TIBC was significantly decreased in IS group in comparison to their baseline value. These changes were due to supplementation of iron to both groups. Again, serum iron levels were significantly increased and serum TIBC level was significantly decreased in IAS group in comparison to IS group. These differences were due to Amloki supplementation. Vitamin C present in amloki, causes reduction of ferric to ferrous form and keeps the ferrous salts in soluble condition for its better absorption. However, the exact mechanisms involved in improvement of iron status by oral amloki supplementation cannot be elucidated from the present study as the phytochemical analysis of amloki were not done. 


\section{Conclusions}

The results of the study, concluded that oral Emblica officinalis (amloki) can effectively improve iron status in pregnant women with iron deficiency anemia. Therefore oral supplementation of amloki along with iron may be helpful to treat iron deficiency anemia in pregnancy.

\section{Acknowledgement}

The authors acknowledge Department of Obstetrics and Gynaecology, Dhaka Medical College and Hospital, Dhaka and Department of Pharmaceutical Chemistry, Faculty of Pharmacy, University of Dhaka for their kind cooperation.

\section{References}

1. Layeeq S, Thakar AB. Clinical efficacy of amloki rasayana in the management of pandu (iron deficiency anemia). Ayu 2015; 36(3): 290-97.

2. Colledge NR, Walker BR, Raltson SH, editors. Davidson's principles \& practice of medicine. $21^{\text {st }}$ ed. China: Elsevier 2010; Blood disease; 1017 p.

3. WHO. Anemia prevalence, causes and consequences [Internet] Geneva: World Health Organization: c 2008 [Cited 2017 Jan 11] Available from: http:// www.k4health.org/toolkits/anemia-prevention/ anemia-causes-p

4. Ahmed F. Anaemia in Bangladesh: a review of prevalence and aetiology. Public Health Nutr 2000; 3(4):385-93.

5. Kumar P, Clark M. Kumar \& Clark's Clinical Medicine, $8^{\text {th }}$ ed. Spain: Saunders Elsevier 2012; Iron deficiency anaemia; 371- $430 \mathrm{p}$.

6. Sharp P, Srai SK. Molecular mechanisms involved in intestinal iron absorption. World J Gastroenterol 2007; 13(35): 4716-24.

7. Terri D, Wimbley J, Graham DY. Diagnosis and management of iron deficiency anaemia in the $21^{\text {st }}$ century. Ther Adv Gastroenterol 2011; 4(3): 177-84.

8. Roy A, Dwivedi M. Dhatrilauha: right choice for iron deficiency anemia in pregnancy. Ayu 2014; 35(3):283-88.

9. Sharma R, Jain N, Rani D, Jaitawat A, Kantawa SM. Role of Emblica Officinalis and Foeiniculum vulgare

J Bangladesh Soc Physiol. 2019, June; 14(1): 1-6 during pregnancy and lactation. Int $\mathrm{J} \mathrm{Adv}$ Multidisciplinary Res 2015; 2(4): 103-13.

10. Joshi N, Dash MK, Dwivedi LK,Khilani GD. Clinical evaluation of ayurvedic iron (Lauha) containing preparations in iron deficiency anaemia. Int $\mathrm{J}$ Res Ayurveda Pharma 2015; 6(2): 225-31.

11. Ramadevi G, Jonah S, Prasad UN.A clinical study on the effect of dhatri lauha in garbhinipandu (iron deficiency anaemia). Int. J. Res. Ayurveda Pharm 2014; 5(6): 708-12.

12. Harper JL. Iron Deficiency Anemia Workup [Internet]. Newyork : Web Med: c 2016 [Cited 2017 Feb 06]. Available from: http:///emedicine. medscape. com/article/202333-workup

13. Dasaroju S, Gottumukkala KM. Current trends in the research of Emblica officinalis (Amla): A pharmacological perspective. Int J Pharm Sci Rev Res 2014; 24(2): 150-59.

14. Govind P, Pandey SP. Phytochemical and toxicity study of Emblica officinalis (Amla). Int Res J Pharmacy 2011; 2(3): 270-72.

15. Jain R, Pandey R, Mahant RN, Rathore DS. A review on medicinal importance of Emblica officinalis. Int J Pharm Sci Res 2015; 6(1): 73-84.

16. Chaudhury K. Amla berry: The modern foundation of youth [Internet] Herpo: OZ EXPERTS; 2017 [Cited 2017 Jan 07]. Available from: http:// blog.doctoroz.com/oz-experts/amla-bery-themodern-foundation

17. Klemn RDW, Sommerfelt AE, Boyo A, Barba C, Kotecha P, Steffen M, Franklin N. Are we making progress on reducing anemia in women? [Internet] Washington: United States Agency for International Development: c 2011 [Cited 2017 Jan o9] Available from: http://www.a2zproject.org/pdf/ ReducingAnemia_low_res_06212011.pdf.

18. Khot BM, Patil AJ, Kakad AC. Comparative clinical study of dhatri lauha and navayasa lauha in garbhini panduroga with reference to anemia in pregnancy. Int Org Sci Res J Dental Med Sci 2013; 11(1): 2833.

19. Venkatasubramanian P, Koul IB, Varghese RK, Koyala S, Shivakumar A. Amla enhances iron dialysability and uptake in in-vitro models. Current sci 2014; 107(11): 1859-64.

20. Rupara AV, Donga SB, Dei L. A comparative study on the effect of pandughnivati and dhatrilauhavati 
in the management of garbhinipandu (iron deficiency anemia). Ayu 2013; 34(3): 276-80.

21. Khandelwal DA, Donga SB, Dei L. Clinical efficacy of punarva mandura and dhatrilauha in the management of garbhini pandu (anemia in pregnancy). Ayu 2015; 36(4): 397-403.

22. Benjwal S. Role of amalaki (Emblica officinalis) churna in iron deficiency anemia in pregnant women. Ayurpharm Int J Ayur Alli Sci 2013; 2(2):48-51.

23. Siu AL. Screening for iron deficiency anaemia and iron supplementation in pregnant women to improve maternal health and birth outcomes: U.S preventive services task force recommendation statement. Ann Intern Med 2015; 163(7): 529-36.
24. Allen LH, Ahluwalia N. Improving iron status through diet. Washigton DC: USAID, Opportunities for micronutrients intervention 1997; Bioavailibility of nonheme iron; p. 13-54.

25. Brugnara C, Beris P. ESH handbook on disorders of iron metabolism. Paris: European school of haematology 2009; Chapter 21, Iron therapy; 512$29 \mathrm{p}$.

26. Short MW, Domagalski JE. Iron deficiency anemia: evaluation and management. Am Fam Physician 2013; 87(2):98-104.

27. Clark SF. Iron deficiency anaemia: diagnosis and management. Curr Opin Gastroenterol 2009; 25: $122-8$. 